\title{
SPECYFIKA EKONOMICZNEJ OCENY REGIONALNEJ POMOCY PAŃSTWA W UNII EUROPEJSKIEJ
}

\begin{abstract}
Streszczenie
Publiczne wsparcie przedsiębiorstw $\mathrm{w}$ formie dotacji, ulg podatkowych, czy też gwarancji podejmowane jest w celu oddziaływania na ich decyzje dotyczące np. wejścia na rynek, lokalizacji ich działalności, działalności badawczo-rozwojowej, wielkości produkcji i zatrudnienia. Ukierunkowanie interwencji na zawodności rynku ma istotne znaczenie dla jej efektywności, a potencjalne ograniczenia konkurencji i handlu związane ze wsparciem stanowią uzasadnienie kontroli pomocy państwa w Unii Europejskiej.

Celem niniejszego artykułu jest charakterystyka ekonomicznych aspektów regionalnej pomocy państwa w Unii Europejskiej. Analiza ta przybliża zarówno ekonomiczne uzasadnienie tego rodzaju interwencji, jak i ocenę jej dotychczasowych efektów.
\end{abstract}

Słowa kluczowe: pomoc regionalna, Unia Europejska.

\section{Wstęp}

Kontrola pomocy państwa w Unii Europejskiej postrzegana jest, jako najbardziej restrykcyjna regulacja $w$ tej materii na świecie. Jej specyfiką jest istnienie kontroli zarówno przed (ex ante), jak i po (ex post) udzieleleniu wsparcia przedsiębiorstwu (OECD, 2010). Ponadto, od 2005 r. następuje proces ekonomizacji tego obszaru polityki konkurencji Unii Europejskiej, uzasadniony w istotnej mierze chęcią ograniczenia i lepszego ukierunkowania tego rodzaju interwencji.

Celem niniejszego artykułu jest scharakteryzowanie ekonomicznego podejścia do kontroli pomocy państwa w Unii Europejskiej, na przykładzie pomocy regionalnej. Dlatego też dwie pierwsze części tego opracowania przybliżają specyfikę tej kategorii interwencji, a kolejna część opisuje jej ekonomiczne uzasad- 
nienie. Część czwarta poświęcona została opisowi głównych rodzajów wsparcia przedsiębiorstw w UE w ramach pomocy regionalnej, a w ostatniej część przybliżono wyniki badań na temat efektów tego wsparcia.

\section{Pojęcie pomocy regionalnej}

Głównym celem polityki konkurencji jest zagwarantowanie braku zakłóceń konkurencji na rynku, które mogłyby prowadzić do ograniczenia dobrobytu. W przypadku Unii Europejskiej polityka ta, poza dysponowaniem typowymi instrumentami (tj. regulacjami dotyczącymi porozumień ograniczających konkurencję, zakazem nadużycia pozycji dominującej, czy też kontrolą koncentracji przedsiębiorstw) obejmuje również specyficzny obszar, jakim jest kontrola pomocy państwa. Szczególny charakter tego obszaru polityki konkurencji Unii Europejskiej wiąże się z tym, że źródłem potencjalnych ograniczeń konkurencji jest wsparcie udzielane przez państwo prywatnym lub publicznym przedsiębiorstwom, a nie zachowania przedsiębiorstw (Haucap, Schwalbe, 2011). Z tego też względu paragraf 1 arykułu 107 Traktatu o Funkcjonowaniu Unii Europejskiej (TFUE) przewiduje generalny zakaz pomocy państwa. Pozostałe dwa paragrafy tego artykuły wskazują jednak wyjątki od tego ogólnego zakazu, a jednym z nich jest pomoc regionalna. Inne dopuszczalne formy pomocy państwa pogrupowane są w dwie kategorie pomocy - sektorową i horyzontalną. Pomocą sektorową objęte są przedsiębiorstwa z następujących sektorów: górnictwa węgla, wytwarzania energii eletrycznej, kinematografii, gazu ziemnego, telekomunikacyjnego i bankowego. Pomoc horyzontalna skierowna jest natomiast do wszystkich przedsiębiorstw, niezależnie od ich lokalizacji lub sektora działalności gospodarczej, i obejmuje publiczne wsparcie przeznaczone na: prace badawczo-rozwojowe, ochronę środowiska, zatrudnienie, szkolenia, restrukturyzację, naprawę szkód wyrządzonych przez klęski żywiołowe lub inne nadzwyczajne zdarzenia, promowanie kultury, nauki i oświaty oraz ochronę dziedzictwa kulturowego, pomoc o charakterez socjalnym dla indywidualnych konsumentów oraz pomoc na działalność sportową i rekreacyjną.

Pomoc regionalną definuje się jako pomoc udzieloną przez państwo członkowskie Unii Europejskiej przedsiębiorstwom na wspieranie rozwoju gospodarczego niektórych regionów UE znajdujących się $\mathrm{w}$ niekorzystnym położeniu (Komisja Europejska, 2013). Tego rodzaju interwencja przyjmuje najczęściej formę wsparcia inwestycji i kreacji zatrunienia udzielanego przedsiębiorstwom prowadzącym działalność gospodarczą na obszarach, które z powodów ekonomicznych lub strukturalnych znajdują się $\mathrm{w}$ niekorzystnej sytuacji. Tym samym pomoc regionalna postrzegana jest jako jedno $\mathrm{z}$ narzędzi polityki rozwoju gospodarczego państw członkowskich Unii Europejskiej, wspierające ważne cele UE, tj. przyspieszenie spójności ekonomicznej, społecznej i terytorialnej (Friederiszick, Merola, 2015). 


\section{Znaczenie pomocy regionalnej w strukturze pomocy państwa $\mathrm{w}$ Pol-} sce

Przed wejściem do Unii Europejskiej, pomoc regionalna w Polsce nie stanowiła istotnej części pomocy państwa. Największa część pomocy przeznaczona była na pomoc sektorową. Podobną sytuację można było zaobserwować $\mathrm{w}$ tym okresie w innych krajach Europy Środkowo-Wschodniej (EŚW), co wyjaśnia się procesem trasformacji i związaną z nim restrukturyzacją sektorów waunkująca proces prywatyzacji, a także regulacjami dotyczącymi pomocy $w$ niektórych sektorach $\mathrm{w}$ okresie przejściowym (np. w Polsce reguły te dotyczyły sektora wydobycia węgla kamiennego, czy też sektora hutniczego) (Hölscher, Nulsch, Stephan, 2017).

Wejście krajów EŚW do Unii Europejskiej wymusiło stopniowe ograniczanie pomocy sektorowej na rzecz zwiększenia pomocy o charakterze horyzontalnym i regionalnym. Dane przytoczone przez Hölscher et al. (2017) ukazuja że w dziesięciu krajach EŚW, kóre przystąpiły do UE w roku 2004 i roku 2007, pomoc sektorowa w 2004 r. stanowiła 70\% całkowitej pomocy publicznej, a rok później zmniejszyła się do 36\%, nastomiast w 2013 r. do 7\% całkowitej pomocy państwa udzielonej $\mathrm{w}$ tych krajach. $\mathrm{W}$ okresie tym zaobserwowano natomiast istotny wzrost udziału pomocy horyzontalnej - z 15\% w $2004 \mathrm{r}$. do 58\% udziału w całkowitej pomocy państwa w krajach EŚW w 2013 r. Nieco mniejszy wzrost nastąpił $\mathrm{w}$ trzeciej kategorii pomocy - tj. w pomocy regionalnej - z 15\% w 2004 r. do 35\% udziału w całkowitej pomocy państwa w krajach EŚW w 2013 r. (Hölscher et al., 2017).

Dane z okresu 2009-2016 na temat struktury pomocy państwa w Polsce świadczą o utrzymującej się dominacji pomocy horyzontalnej, a także o dużym znaczeniu pomocy regionalnej oraz niebagatelnym udziale pomocy sektorowej (rysunek 1.). Istotny udział pomocy horyzontalnej w pomocy państwa ogółem uznać można za pozytywne działanie $\mathrm{w}$ dążeniu do wypełnienia celu postawionego przed Unią Europejską w takich strategicznych dokumentach, jak Strategia Lizbońska, czy Strategia Europa 2020, tj. uczynieniem gospodarki UE intelignetną i zrównoważoną, sprzyjającą włączeniu społecznemu, osiągającą wysokie wskaźniki zatrudnienia i wydajności oraz wysoką spójność społeczną (Komisja Europejska, 2010). 


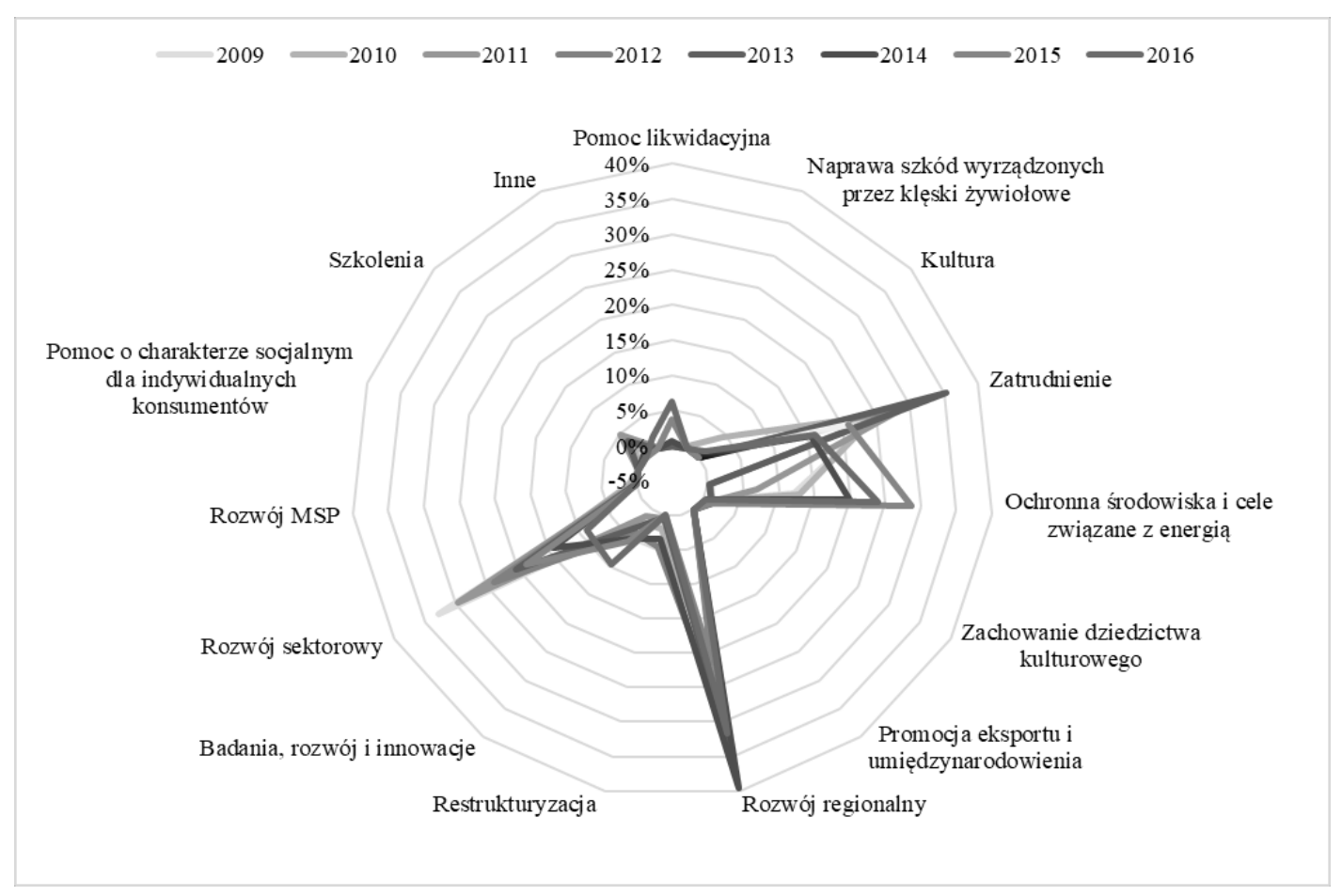

Rysunek 1. Struktura pomocy państwa w Polsce w latach 2009-2016, z wyłączeniem pomocy dla rolnictwa i transportu

Źródło: Opracowanie własne. State Aid Scoreboard 2017, Country Fiche Poland 2017, http://ec.europa.eu/competition/state aid/scoreboard/index en.html

Wspomniane wyżej strategiczne dokumenty UE oparte są $\mathrm{w}$ istotnym stopniu na nowej teorii wzrostu Romera $(1986,1990)$, zgodnie z którą długookresowy wzrost gosporadczy uzyskiwany jest dzięki endogenizacji postępu technicznego, będącego efektem prac badawczo-rozwojowych, wspieranych także przez państwo. Z tej pespektywy trudno uznać za zadowalające zjawisko dominacji pomocy na zatrudnienie w strukturze pomocy horyzontalnej w latach 2009-2013, przy niewielkim udziale pomocy na $\mathrm{B}+\mathrm{R}$. Za pozytywną tendencję uznać natomiast można zmniejszający się w ostatnich latach udział pomocy sektorowej w pomocy państwa ogółem oraz istotny udział pomocy na ochonę środowiska w pomocy horyzontalnej. Od 2014 r. zaobserwować również można istotny wzrost wartości pomocy na B+R, co skutkuje wzostem udziału tej kategorii w pomocy państwa ogółem.

Kategorią pomocy, która również wpisuje się w priorytety Strategii Europa 2020, tj. rozwój sprzyjający włączeniu społecznemu, wspierający gospodarkę o 
wysokim poziomie zatrudnienia, zapewniającą spójność społeczną i terytorialna, jest pomoc regionalna (Komisja Europejska, 2010). W przypadku Polski udział tego rodzaju wsparcia przedsiębiorstw w pomocy państwa ogółem był stabliny $\mathrm{w}$ latach 2009-2013, a także we wcześniejszym okresie, tj. w latach 2005-2008 (Ambroziak, 2009, s. 303). Dane na temat struktury pomocy państwa z okresu poprzedzającego wejście Polski do Unii Europejskiej wskazują na niewielkie znaczenie interwencji o charakterze regionalnym, o czym świadczy jej udział w pomocy państwa ogółem, oscylujący między 0,3 a 4,6\% w latach 1996-2003 (Ambroziak, 2009, s. 303).

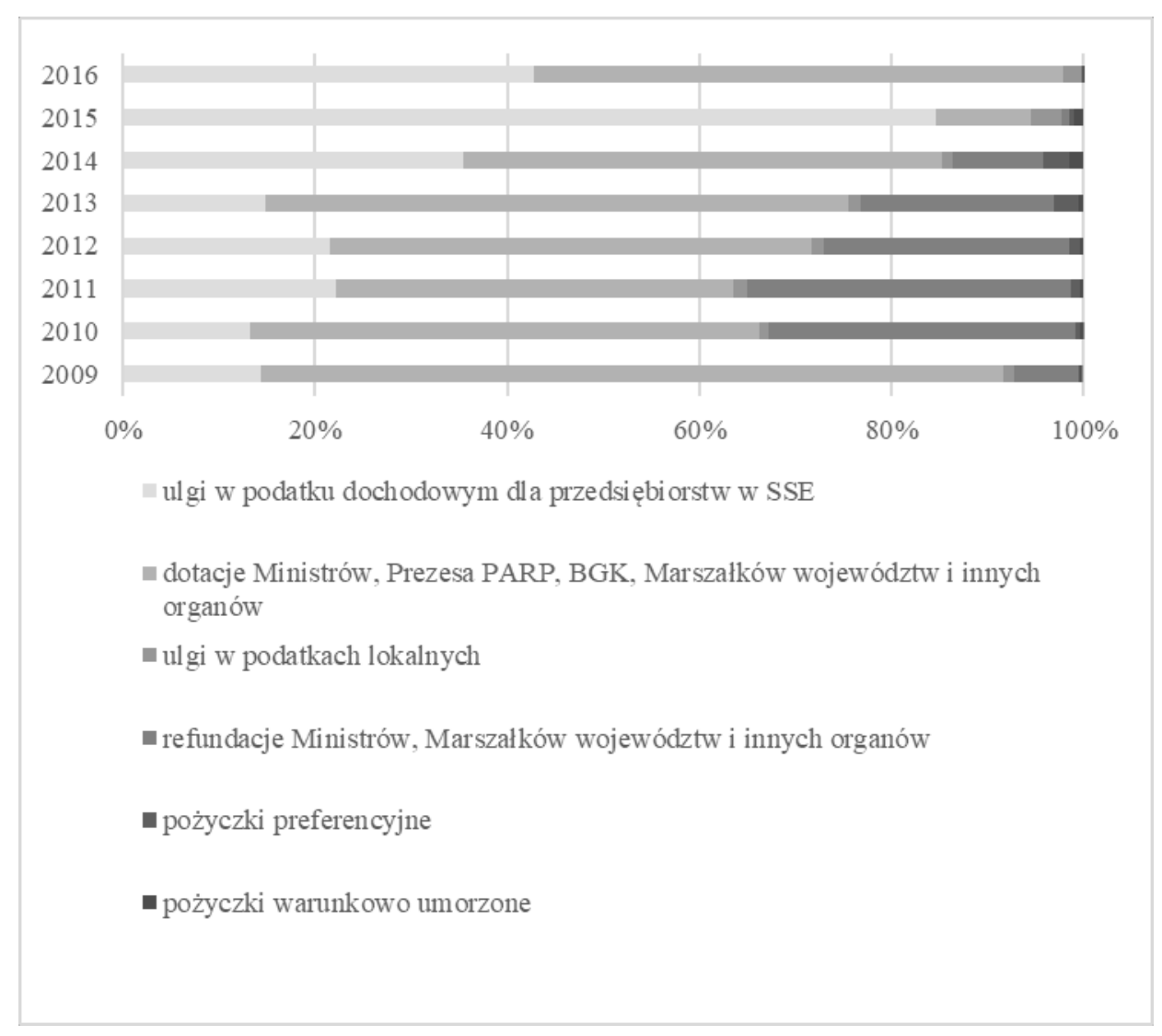

Rysunek 2. Struktura form pomocy regionalnej w Polsce w latach 2009-2016

Źródło: Opracowanie własne. Raporty o pomocy publicznej udzielonej przedsiębiorcom w latach 2009-2016, UOKiK,

https://uokik.gov.pl/raporty_i analizy2.php, opracowania z lat 2009-2016 
Istotne znaczenie dla wzrostu wielkości pomocy regionalnej, a także jej udziału w pomocy państwa ogółem po wejściu Polski do Unii Europejskiej miał dostęp przedsiębiorstw do funduszy strukturalnych oraz rosnące zainteresowanie inwestorów lokalizacją działalności w specjalnych strefach ekonomicznych (SSE). Świadczy o tym istotny udział dotacji i refunadacji oraz ulg w podatku dochodowym dla przedsiębiorstw prowadzących działalność w SSE w pomocy regionalnej ogółem, w latach 2009-2016 (zob. rysunek 2). Specjalne strefy ekonomiczne funkcjonują w Polsce od 1996 r. i w latach 1999-2001 ulgi w podatku, udzielane przedsiębiorstwom fukcjonującym w SSE stanowiły odpowiednio $96 \%$, 99\% i 87\%) (Ambroziak, 2009, s. 306). Taki stan miał związek z rosnącym zainteresowaniem inwestorów zagranicznych SSE, a także z niewielkim znaczeniem innych instrumentów pomocy regionalnej. Przyciaganie inwestorów zagranicznych poprzez oferowanie im ulg podatkowych miało przyczynić się do wzrostu inwestycji w słabiej rozwiniętych regionach, a co z tym związane, do tworzenia nowych miejsc pracy, wzrostu dochodów oraz stymulowania wzrostu gospodarczego. Ulgi podatkowe miały stanowić zachętę dla inwestorów do lokalizacji w obszarach, którymi w przypadku braku interwncji nie byliby zainteresowani. Dlatego też instrument ten, podobnie jak dotacje i refundacje, może być postrzegany jako istotny element polityki rozwoju UE, której celem jest wyrównywanie możliwości wzrostu na obszarze UE.

\section{Ekonomiczne podstawy kontroli pomocy regionalnej}

Friederiszick i inni (2008) wskazują trzy obszary nauk ekonomicznych, z którymi związana jest kontrola pomocy państwa. Pierwszy z nich to ekonomia sektora publicznego, gdyż pomoc państwa jest formą interwencji państwa w gospodarkę. Drugi obszar to ekonomia konkurencji, która koncentruje uwagę na przewadze, jaką zyskują przedsiębiorstwa dzięki uzyskanej pomocy, a która to przewaga może wpływać na proces konkurencji. Trzecim obszarem jest teoria handlu międzynarodowego, która pojawia się w kontekście oddziaływania pomocy państwa na warunki handlu, co stanowi uzasadnienie ponadnarodowej kontroli pomocy państwa, z jaką mamy do czynienia w Unii Europejskiej.

W kontekście ekonomicznej analizy różnych kategorii pomocy państwa najistotniejszy wydaje się pierwszy ze wspomnianych wyżej obszarów, a mianowicie wyjaśnienie motywów interwencji państwa $\mathrm{w}$ gospodarce. Teoria, która ułatwia sformułowanie takiego wyjaśnienia jest ekonomia dobrobytu. Jej teoretycy pozwalają na wyróżnienie dwóch elementów dobrobytu, a mianowicie efektywności i równości (H. W. Friederiszick et al., 2008). Efektywnościowy aspekt wzrostu dobrobytu poprzez intwerwencję wiąże się ze wzrostem efektywności gospodarki i przesunięciem dzięki temu granic dobrobytu na zewnątrz, co czasami obrazowo określane jest jako „making the cake bigger". Z kolei równościowe podejście do wzrostu dobrobytu poprzez interwencję wiąże się z redystrybucją posiadanych zasobów, prowadzącą do maksymalizacji preferencji społeczeństwa 
$\mathrm{W}$ odniesieniu do równości i redystrybucji, co potocznie można określić jako "dividing the cake better" (H. W. Friederiszick et al., 2008).

W kontekście interwnecji państwa skoncentrowanej na wzroście efektywności gospodarki, istotne znaczenie ma zidentyfikowanie zawodności rynku, tj. przyczyn braku uzyskania przez rynek efektywnych wyników w postaci ceny, wielkości produkcji czy też użytych zasobów, a następnie podjęcie działań korygujących te zawodności, o ile korzyści płynące z interwnecji przewyższają jej koszty (H. W. Friederiszick et al., 2008).

Mimo że interwnecja publiczna $\mathrm{w}$ ramach pomocy regionalnej $\mathrm{w}$ istotnym stopniu wydaje się opierać na celu równościowym (zob. Komisja Europejska, 2013), to jednak kluczem do jej zrozumienia jest zawodność rynku. Jak podkreślają Friederiszick i Merola (2015), zawodności rynku powinny być uwzględnione w ekonomicznej ocenie intstrumentów pomocy regionalnej z dwóch powodów. Pierwszym z nich jest to, że horyzontalne instrumenty skierowane na zawodność rynku (np. związane z kapitałem wysokiego ryzyka, czy szkoleniami) mogą mieć także pośedni wpływ regionalny. Drugim powodem jest to, że tylko ukierunkowanie interwencji na lokalną zawodność rynku umożliwia osiągnięcie długookresowych efektywnościowych efektów (tj. np. wzrost produktywności).

Z punktu widzenia pomocy regionalnej za najważniejsze zawodności rynku na poziomie lokalnym uznaje się (H. Friederiszick \& Merola, 2015):

- korzyści aglomeracji,

- dobra publiczne lub quasi publiczne,

- niedoskonałości lokalnych rynków kapitałowych,

- wcześniejsze interwencje rządowe.

Efekty aglomeracji, tj. związek między miarami lokalnej gęstości a produktywnością stanowią podstawę zrozumienia logiki pomocy regionalnej. Analiza literatury przedmiotu pozwala wnioskować, że wzrost lokalnej gęstości (mierzonej np. liczbą mieszkańców na kilometr kwadratowy) prowadzi do wzrostu produktywności przedsiębiorstw aktywnych $\mathrm{w}$ danym regionie (Combes, Ypersele, 2013). Stąd też efekty aglomeracyjne mogą stanowić wyjaśnienie przyczyn przyciagania przez rządy przedsiębiorstw do pewnych regionów. Efekty te wyjaśniają również konieczności tworzenia zachęt dla inwestorów w peryferyjnych obszarach, które nie osiaggnęly jeszcze masy krytycznej. W takich okolicznościach zachęty oferowane przedsiębiorstwom uznać należy za rekompensatę z rezygnacji z możliwości lokalizacji działalności w bardziej atrakcyjnych regionach (Friederiszick, Merola, 2015).

Z kolei ukierunkowanie interwencji publicznej na dobra publiczne, tj. lokalną i regionalną infrastrukturę, umożliwia poprawę lokalnej dostępności, przyczyniając się do zwiększenia efektywności działalności przedsiębiorstw. Poprawa efektywności działalności przedsiębiorstw może także nastąpić poprzez publiczne wsparcie lokalnych przedsiębiorstw mających ograniczony dostęp do finan- 
sowania rozwoju, czy też ukierunkowanie interwencji na takie zawodności rynku, jak np. sztywność lokalnego rynku pracy.

Identyfikacja lokalnych zawodności rynku, a następnie geograficzne ukierunkowanie interwencji rządu niosą ze sobą potencjał poprawy regionalnej efektywności, a tym samym regionalnego wzrostu. Ponadto, przezwyciężenie lokalnych zawodności rynku lub eksploatacja efektów aglomeracji umożliwiają osiągnięcie trwałych korzyści w ramach teorematu równościowego. Innym słowy, mimo że pomoc regionalna jest często motywowana celem równościowym (tj. inclusive growth), to uwzględnienie $\mathrm{w}$ interwencji regionalnej lokalnych zawodności rynku ma istotne znaczenie dla trwałego, długookresowego wzrostu tych obszarów (tj. sustainable growth) (Friederiszick, Merola, 2015).

\section{Regionalne programy wsparcia przedsiębiorstw w Unii Europejskej}

Państwa Unii Europejskiej stosują wiele różnorodnych form wsparcia przedsiębiorstw $\mathrm{w}$ ramach pomocy regionalnej. Programy te mogą mieć zasięg lokalny lub regionalny, mogą być skierowane do wszystkich przedsiębiorstw albo tylko do wybranych sektorów, czy też przybrać formę dyskrecjonalnych dotacji, ulg podatkowych dla nowych inwestorów albo interwencji ukierunkowanej na poprawę regionalnej infrastruktury. Próbę klasyfikacji różnorodnych regionalnych programów wsparcia podjęli Neumark i Simpson (2014), którzy wyróżnili pięć kategorii programów ukierunkowanych na przedsiębiorstwa.

Pierwszą z nich są strefy przedsiębiorczości (Enterprise zones), których celem jest kreacja miejsc pracy na przedmieściach większych miast lub w częściach miast charakteryzujących się wysoką stopą ubóstwa i bezrobocia. Przykład mogą stanowić francuskie miejskie strefy (Zones Franches Urbaines-ZFU), w ramach których zlokalizowane $w$ granicach strefy przedsiębiorstwa, zatrudniające mniej niż 50 pracowników, są zwolnione z lokalnych podatków oraz składek na ubezpieczenia społeczne od wynagrodzeń niższych niż 1,4 minimalnego wynagrodzenia. Zwolnienia te są stopniowo wygaszane po początkowych pięciu latach korzystania $\mathrm{z}$ tej formy wsparcia.

Druga kategoria to dyskrecjonalne granty, których celem jest zazwyczaj przyciagnięcie nowych przedsiębiorstw i inwestycji do pewnych obszarów, a także kreacja miejsc praca lub zachowanie miejsc pracy. Przykładem tego rodzaju programu jest Prime d'Aménagement du Territoire (PAT), w ramach którego przedsiębiorstwom przyznawano granty $\mathrm{w}$ celu kreacji lub zachowania zatrudnienia $\mathrm{w}$ słabiej rozwiniętych regionach Francji. Podobny charakter miał również Regional Selective Assistance (RSA) Scheme w Zjednoczonym Królestwie oraz włoski program znany pod nazwą The Italian Law 488. Także flamandzki program wspierający inwestycje małych i średnich przedsiębiorstw uznać można za zbliżony do włoskiego The Italian Law 488. Cechą tego rodzaju programów są dotacje dla przedsiębiorstw udzielane na nowe inwestycje, których celem jest kreacja lub utrzymanie zatrudnienia, a także przyciągnięcie zagranicznych inwestycji bezpo- 
średnich. Ponadto przyznawanie wsparcia ma charakter dyskrecjonalny, tzn. oparte jest na ocenie case-by-case lub na systemie przyznawania punktów, co stanowi również podstawę krytyki tego rodzaju programów.

Neumark i Simpson (2014) wyróżnili również kategorię wsparcia przedsiębiorstw, która nie mieści się $\mathrm{w}$ ramach powyższych dwóch i nazwali ją inicjatywami rozwoju o charakterze lokalnym. Cechą tych programów jest lokalna autonomia $w$ zakresie projektowania interwencji oraz wydawania środków publicznych. Europejskim przykładem może być ustanowiony w 1997 r. włoski program Patti Territoriali, którego celem była stymulacja wzrostu zatrudnienia $\mathrm{w}$ słabo rozwinięnty regionach, które zgodnie z unijnym prawem uprawnione były do wsprcia o charakterze regionalnym. Wsparcie $\mathrm{w}$ ramach tego programu przeznaczone zostało zarówno na inwestycje w publiczną infrastrukturę, jak też na prywatne inwestycje $\mathrm{w}$ regionach objętych programem. Zbliżony charakter miał uruchomiony w 2002 r. w Anglii program New Deal for Communities, ukierunkowany na poprawę jakości życia najbardziej opóźninych regionów w tym kraju. Program ten koncentrował się na wsparciu zatrudnienia (w tym, otwieraniu działalności gospodarczej) i edukacji, a także ograniczeniu przestępczości, poprawie zdrowia oraz sytuacji na lokalnych rynkach nieruchomości. Podobną naturę do Patti Territoraili wydają się mieć strefy przedsiębiorczości w Zjednoczonym Królestwie oraz programy wspierające inwestycje we wschodniej części Niemiec. W ramach tych programów nowi inwestorzy w opóźnionych regionach mogli korzystać z obniżonych obciążeń podatkowych oraz przyspieszonej amortyzacji kapitału. Działania te nie zostały ukierunkowane na specyficzne sektory i nie miały charakteru dyskrecjonalnego, gdyż wszystkie przedsiębiorstwa spełniające warunki przyznania pomocy miały do niej prawo (Friederiszick, Merola, 2015). Z uwagi na powyższe cechy istniejące w Polsce SSE również można zakwalifikować do tej kategorii programów.

Kolejną kategorią wyróżnioną przez Neumark i Simpson (2014) są programy promujące klastry i uniwersytety jako narzędzia wspierające lokalny rozwój gospodraczy. Przykładem może być Francja, w której przyjęto politykę dotyczącą klastrów, a także Zjednoczone Królestwo, w którym klastry stanowią część programu stref przedsiębiorczości. W ramach francuskiej polityki stworzono lokalne systemy produktywności (Local Productive Systems (LPS), w ramach których przyznawane było finansowe wsparcie na współpracę między przedsiębiorstwami z tego samego sektora i obszaru. Polityka klastrowa była także stosowana przez niemiecką Bawarię w latach 1999-2004, a ukierunkowana została na poprawę wyników przedsiębiorstw oraz badań sektora publicznego $\mathrm{w}$ obszarze pięciu sektorów wysokich technologii. Cechą tego rodzaju programów jest to, że koncentrują się one na przywództwie technologicznym lub doskonałości, a nie na przyspieszeniu rozwoju w zapóźnionych regionach.

Wsparcie rozwoju opóźnionych regionów może również przybrać formę wsparcia inwestycji w infrastrukturę, np. energetyczna, telekomunikacyjną czy 
też związaną z B+R. Głównym instrumentem finansownia tego rodzaju działań w Unii Europejskiej są fundusze europejskie,a zwłaszcza Europejski Fundusz Rozwoju Regionalnego (EFRR), Europejski Fundusz Społeczny (EFS) oraz Fundusz Spójności. Poza finansowaniem projektów infrastrukturalnych w ramach EFRR, przyznawane są dotacje inwestycyjne dla przedsiębiorstw, a w ramach EFS dotacje na zatrudnienie.

\section{Efekty regionalnych programów wsparcia przedsiębiorstw w Unii Europejskej}

Od 2005 r. zaobserwować można działania Unii Europejskiej zmierzające do zreformowania pomocy państwa (Commission of European Communities, 2005). Jednym $\mathrm{z}$ istotnych elementów tej reformy jest skoncentrowanie uwagi na jakości i efektywności interwencji (Komisja Europejska, 2012). Realizacja tego celu odbywa się poprzez ściślejszą kontrolę pomocy o znaczącym wpływie na jednolity rynek oraz jej ewaluację zalecaną przez Komisję Europejską. Wiedza zdobyta dzięki ewaluacji dużych programów pomocy ma się przyczynić do polepszenia efektywności publicznej interwnecji, lepszego rozporządzania wydatkami publicznymi oraz ograniczenia zakłóceń na jednolitym rynku (European Commission Competition DG, 2013).

W kontekście regionalnej pomocy państwa zauważyć należy istnienie obecnie wielu wyników badań poświęconych efektywności publicznego wsparcia przedsiębiorstw $\mathrm{w}$ ramach programów realizowanych $\mathrm{w}$ krajach Europy Zachodniej. Badania te przyjmują najczęściej formę ewaluacji ex-post, która jako miarę efektywności przyjmuje zazwyczaj liczbę bezpośrednio lub pośrednio utworzonych miejsc pracy oraz wielkość dodatkowych inwestycji zrealizowanych dzięki publicznemu wspraciu. Ponadto wielkości te są przedstawiane w relacji do wydanych środków publicznych na ten cel. Z kolei miarą długookresowych efektów tego rodzaju interwencji jest produktywność, mierzona zazwyczaj jako TFP.

Francuskie strefy miejskie (ZFU) stanowiły przedmiot badań Mayer et al (2012) oraz Givord et al. (2013). Autorzy ci uzyskali podobne wyniki wskazujące na pozytywny wpływ wsparcia na kreację przedsiębiorstw oraz zatrudnienie, przy czym program ten przyczynia się do realokacji przedsiębiorstw z obszarów danego miasta nieobjętych wsparciem do obszarów poddanych interwencji. Ponadto wyniki badania Givord et al. (2013) ukazuja, że wpływ interwencji na przedsiębiorstwa zlokalizowane przed interwencją na obszarze objętym wspraciem nie jest statystycznie istotny, natomiast Mayer et al. (2012) uzyskali zróżnicowane wyniki pomiędzy poszczególnymi strefami, przedsiębiorstwami i sektorami oraz relatywnie wysoki koszt realokoacji przedsiębiorstw.

Heterogeniczność wyników zaobserwować również można w badaniach poświęconych dyskrecjonalnym grantom. Crozet et al. (2004), analizując wpływ publicznych grantów inwestycyjnych dla przedsiębiorstw - francuskiego Prime d'Aménagement $d u$ Territoire oraz funduszy strukturalnych - ustalili znikomy po- 
zytywny wpływ tych instrumentów na faktyczny wybór lokalizacji przez inwestorów. Podobne wnioski zostały sformułowane przez Devereux et al.(2007) w badaniu poświęconym oddziaływaniu Regional Selective Assistance na decyzje lokalizacyjne przedsiębiorstw.Wyniki ich badań wskazują także na zróżnicowany wpływ dotacji na wybór lokalizacji uzależniony od liczby istniejących $\mathrm{w}$ danej lokalizacji przedsiębiorstw $\mathrm{z}$ tego samego sektora. Ten sam program stanowił także przedmiot badania przeprowadzonego przez Criscuolo et al. (2016). Autorzy ci ustalili, że dotacje miały pozytywny wpływ na wejścia netto nowych przedsiębiorstw, inwestycje przedsiębiorstw, lecz nie miały wpływu na TFP. Poza tym, interwencja miała wpływ wyłącznie na małe przedsiębiorstwa, natomiast duże podmioty nie zamieniały swojej aktywności na skutek wsparcia. Zróżnicowane wyniki interwencji dla przedsiębiorstw o różnej wielkości są widoczne również $\mathrm{w}$ badaniach dotyczących the Italian Law 488 przeprowadzonych przez Bernini i Pellegrini (2011). Również w przypadku tego instrumentu wpływ interwncji na wzrost przychodów i zatrudnienia jest większy w przypadku małych przedsiębiorstw. Interesującym wnioskiem płynącym $\mathrm{z}$ tego badania, a także z badania przeprowadzonego przez Cerqua i Pellegrini (2014), jest negatywny lub znikomy wpływ wsparcia na długookresową produktywność i wzrost, co istotnie ogranicza pozytywny krótkookreswy wpływ tego instrumentu na przychody, zatrudnienie i aktywa trwałe. Zapewne wyniki tych badań zainspirowały autorów do podjęcia dodatkowych analiz nad związkiem między subsydiami a TFP, czego efektem jest wspólny artykuł Bernini, Cerqua i Pellegrini (2017), którego wyniki wskazują że negatywny wpływ subsydiów kapitałowych na TFP występuje w krótkim okresie, a po 3-4 latach pojawiają pozytywne efekty, uzyskane w głównej mierze dzięki zmianie technologicznej.

Zróżnicowanie wyników obecne jest również $\mathrm{w}$ badaniach poświęconych inicjatywom rozwoju o charakterze lokalnym. Badanie angielskiej inicjatywy New Deal for Communities przeprowadzone przez Romero (2009) wskazuje na pozytywny redystrubucyjny efekt programu, przy zróżnicowanym (uzależnionym od statusu beneficjentów programie) jego wpływie na zatrudnienie. Z kolei badanie Accetturo i de Blasio (2012) ewaluujące włoski program Patti Territoriali nie ukazało żadnego pozytywnego wpływu interwencji na kreację zatrudnienia i przyciąganie nowych inwestorów. Wyjaśnieniem takich wyników, wskazanym przez autorów, może być zbyt mała ilość środków finansowych przeznaczonych na ten program, a także słabość kreowanej własności oraz uzależnienie opóźnionych regionów od interwencji publicznych na dużą skalę.

\section{Zakończenie}

Pomoc regionalną uznać można za istotną kategorię pomocy państwa zarówno w Unii Europejskiej, jak i w Polsce. W przypadku Polski podstawowymi instrumentami pomocy regionalnej są ulgi podatkowe przyznawane przedsię- 
biorstwom funkcjonującym w SSE oraz dotacje przyznawane przedsiębiorstwom $\mathrm{w}$ ramach funduszy strukturalnych UE.

Wyzwaniem w ekonomicznej ocenie działań pomocy regionalnej (zarówno ex ante, jak i ex post) jest to, że nie jest ona oparta na jednym celu. Celami tymi są efektywność i równość.

Zróżnicowanie programów wsparcia przedsiębiorstw w ramach pomocy regionalnej w Unii Europejskiej utrudnia przeprowadzenie ich szerokiej analizy ex post. Dlatego też większość badań $\mathrm{w}$ tym obszarze poświęcona jest analizie efektów indywidualnych programów.

Ogólny wniosek płynący z badań na temat wpływu pomocy regionalnej na wyniki przedsiębiorstw to heterogeniczność wyników. Przyczynami tej różnorodności wydaje się być dobór zmiennych, wielkość przedsiębiorstw, okres, którego dotyczy badanie, a także wielkość wsparcia. Kontynuacja badań w tym obszarze pozwoliłoby na ustalenie czynników determinujacych konkretny wynik, co może mieć istotną wartość dla decydentów i podatników.

\section{Bibliografia}

Accetturo, A., \& Blasio, G. De. (2012). Policies for local development: An evaluation of Italy's "Patti Territoriali." Regional Science and Urban Economics, 42(1-2), 15-26. https://doi.org/10.1016/j.regsciurbeco. 2011.04.005

Ambroziak, A. A. (2009). Krajowa pomoc regionalna w specjalnych strefach ekonomicznych w Polsce. Warszaw: Szkoła Główna Handlowa w Warszawie.

Bernini, C., Cerqua, A., \& Pellegrini, G. (2017). Public subsidies, TFP and efficiency: A tale of complex relationships. Research Policy, 1-17. https://doi.org/10.1016/j.respol.2017.02.001

Bernini, C., \& Pellegrini, G. (2011). How are growth and productivity in private firms affected by public subsidy? Evidence from a regional policy. Regional Science and Urban Economics, 41(3), 253-265. https://doi.org/10.1016/ j.regsciurbeco.2011.01.005

Cerqua, A., \& Pellegrini, G. (2014). Do subsidies to private capital boost fi rms ' growth? A multiple regression discontinuity design approach is. Journal of Public Economics, 109, 114-126. https://doi.org/10.1016/ j.jpubeco. 2013.11.005

Combes, Pierre-Philippe, Ypersele, T. Van. (2013). The role and effectiveness of regional investment aid. The point of view of the academic literature. Luxemburg: European Commission.

Commission of European Communities. (2005). State Aid Action Plan. Less and better targeted state aid: a roadmap for state aid reform 2005-2009. COM, 107 final. 
Criscuolo, C., Martin, R., Overman, H. G., \& Reenen, J. Van. (2016). The Causal Effects of an Industrial Policy. CEP Discussion Paper No 1113 Revised January 2016 ( Replaced January 2012 Version ), 2016(1113).

Crozet, M., Mayer, T., \& Mucchielli, J. (2004). How do firms agglomerate? A study of FDI in France, 34, 27-54. https://doi.org/10.1016/S01660462(03)00010-3

Devereux, M. P., Griffith, R., \& Simpson, H. (2007). Firm location decisions , regional grants and agglomeration externalities. Journal of Public Economics, 91, 413-435. https://doi.org/10.1016/j.jpubeco.2006.12.002

European Commission Competition DG. (2013). Evaluation in the field of State aid. Issues Papers, 12/04/2013, 1-12.

Friederiszick, H., \& Merola, M. (2015). Regional state aid control in Europe : A legal and economic assessment assessment. ESMT Working Papers, 15-05.

Friederiszick, H. W., Röller, L.-H., \& Verouden, V. (2008). European State Aid Control: an economic framework. Handbook in Antitrust Economics, (Chapter 17), 625-671. Retrieved from http://www.esmt.org/fm /312/European_State_Aid_Control.pdf

Givord, P., Rathelot, R., \& Sillard, P. (2013). Regional Science and Urban Economics Place-based tax exemptions and displacement effects: An evaluation of the Zones Franches Urbaines program is. Regional Science and Urban Economics, 43(1), 151-163. https://doi.org/10.1016/ j.regsciurbeco. 2012.06.006

Haucap, J., \& Schwalbe, U. (2011). Economic Principles of State Aid Control. Discussion Paper-Center for European Economic Research - ZEW, (17).

Hölscher, J., Nulsch, N., \& Stephan, J. (2017). State Aid in the New EU Member States *. Journal of Common Market Studies, 55(4), 779-797. https://doi.org/ $10.1111 /$ jcms.12513

Komisja Europejska. (2010). Komunikat Komisji Europa2020. Strategia na rzecz inteligentnego i zrównoważonego rozwoju sprzyjającego włączeniu społecznemu, KOM(2010)2.

Komisja Europejska. (2012). KOMUNIKAT KOMISJI DO PARLAMENTU EUROPEJSKIEGO, RADY, EUROPEJSKIEGO KOMITETU EKONOMICZNO-SPOŁECZNEGO I KOMITETU REGIONÓW Unowocześnienie unijnej polityki $\mathrm{w}$ dziedzinie pomocy państwa. COM, 209 final.

Komisja Europejska. (2013). Wytyczne w sprawie pomocy regionalnej na lata 2014-2020. Dziennik Urzędowy Unii Europejskiej, 2013/C 209, 1-45.

Mayer, T., Mayneris, F., Py, L. (2012). The Impact of Urban Enterprise Zones on Establishments' Location Decisions: Evidence from French ZFUs. Discussion Paper, Institut de Recherches Economiques et Sociales de l'Universite Catolique de Louvain, 19.

Neumark, D., Simpson, H. (2014). Place-Based Policies. Working Paper, Centre for 
Market and Public Organisation, (14/331).

OECD. (2010). Competition, State Aids and Subsidies. Policy Roundtables, (February).

Romer, P.M., Increasing Returns and Long-Run Growth, Journal of Political Economy, 94, 1986, s. $1002-1037$.

Romer, P.M., Endogenous Technological Change, Journal of Political Economy, 98, 1990, s. S71 - S102

Romero, R.G. (2009). Estimating the impact of England's area-based intervention 'New Deal for Communities' on employment. Regional Science and Urban Economics, 39(3), 323-331. https://doi.org/10.1016/ j.regsciurbeco. 2008.11.004

FEATURES OF ECONOMIC ASSESSMENT OF THE EU REGIONAL STATE AID

\section{Summary}

Public subsidies, tax breakes or guarantees are granted to enterpises by public authorities to affect their decisions on market entry, location, R\&D spendings, levels of employment and output. Targeting intervention to market failures is the key issue of its efficiency and potential competition and trade distortions are motivation of the EU state aid control.

The aim of the article is a specification of economic aspects of the regional state aid. It concerns an economic justification of an intervention as well as an economic assessment of its effects.

Keywords: regional state aid, European Union

JEL Classification: *

Nie kasować nic poniżej tej linii 
